Pande skriver videre at American Academy of Pediatrics (AAP) har «vinglet litt frem og tilbake» (1). I sin siste uttalelse, fra september 2012, mente foreningen at fordelene i form av færre urinveisinfeksjoner i første leveår, færre infeksjoner og mindre penil cancer senere teller mer enn ulempene (2).

AAP organiserer 60000 barneleger. De utga sitt første standpunkt om neonatal omskjæring i 1971 og har siden nyansert den i tråd med forskningsfunn. En multidisiplinær arbeidsgruppe gjennomgikk systematisk alle studier om gutteomskjæring publisert mellom 1995 og 2010. Dette førte til en nøye begrunnet Circumcision Policy Statement som sier «..the health benefits of newborn male circumcision outweigh the risks and that the procedure's benefits justify access to this procedure for families who choose it. Specific benefits identified included prevention of urinary tract infections, penile cancer, and transmission of some sexually transmitted infections, including HIV. The American College of Obstetricians and Gynecologists has endorsed this statement» (2).

Altså et klart og utvetydig standpunkt fra verdens fremste barneleger, gynekologer og fødselsleger. Dette forsøker man i lille Norge å så tvil om ved vage påstander om at «Denne uttalelsen har møtt motbør»».

Pandes egen agenda er denne: Hun ønsker ikke et forbud, men et system som i Storbritannia (fra 1948) som kun dekker gutteomskjæring dersom det er medisinsk indikasjon, og som har ført til at «antallet omskjæringer er gått ned». Og så ønsker hun å bruke «de forbud, lover og regler vi allerede har» dersom det skulle oppstå komplikasjoner, som legevaktene visstnok har mange vonde eksempler på.

Det er uklart hvilket problem Pande forsøker å løse i denne artikkelen, annet enn ubehaget hun og andre føler med en skikk som er uvanlig i Norge. Hun har i denne artikkelen ikke fremsatt noen medisinske fakta eller vitenskapelige argumenter som tilsier at gutteomskjæring er til skade for barnet dersom foreldrene ønsker det. Vi etterlyser i det minste en saklig diskusjon av dette temaet. De markante fordelene ved tidlig mannlig omskjæring er ubestridelige på tilgjengelig vitenskapelig grunnlag. Den tyske riksdagen har nylig og med overveldende flertall vedtatt en lov som beskytter og regulerer foreldres rett til neonatal og medisinsk forsvarlig mannlig omskjæring.

Farrukh A. Chaudhry

f.a.chaudhry@biotek.uio.no

Leif Knutsen

Rolf Kirschner

Farrukh A. Chaudhry (f. 1969) er gruppeleder ved Bioteknologisenteret i Oslo, Universitet i Oslo og lege ved Oslo legevakt.

Ingen oppgitte interessekonflikter.

Leif Knutsen (f. 1961) er bedriftsrådgiver og skribent. Han har vært rådgiver for legemiddelfirmaer og helseforsikringsordninger innen bruk av IT og analytiske verktøy innenfor kunnskapsbasert medisin. Ingen oppgitte interessekonflikter.

Rolf S. Kirschner (f.1946) er spesialist i fødselshjelp og kvinnesykdommer og overlege ved Gynekologisk avdeling, Kvinne- og barneklinikken, Oslo universitetssykehus. I 1999 var han leder av Helsedirektoratets tverrfaglig komité for utredning av mannlig omskjæring.

Ingen oppgitte interessekonflikter.

\section{H. Pande svarer:}

Farrukh Chaudhry og medforfatteres kommentars form forundrer meg. Omskjæring av nyfødte gutter må kunne diskuteres uten personangrep («følelser», «fantasier») og dertil en særdeles grov insinuering om at jeg påstår at amerikanere den dag i dag omskjærer sine guttebarn på grunn av redselen for onani. Det er vel kjent at inngrepet nå diskuteres rundt $\mathrm{i}$ verden, og her hjemme kom det nye barneombudet svært raskt ut med krav om forbud. Mediene fulgte opp med hjerteskjærende innlegg om «å skjære i friske guttekropper». Slikt forbud og den slags kampanje tar jeg sterkt avstand fra, og det var første grunn til artikkelen.

Men at inngrepet egentlig er unødvendig, står jeg fortsatt ved etter å ha lest gjennom flere av tusentalls artikler om emnet. Jeg mener også at det er urimelig at vårt helsevesen skal bruke verdifull tid, kapasitet og penger på inngrepet.

Det er vel kjent at for jødene er omskjæring et religiøst påbud (1. Mos. 17) og det bør et hvert sivilisert menneske ha dyp respekt for. Det er imidlertid interessant at Internett-søk på «Jews against circumcision» gir 180000 svar med mange gode motargumenter. Altså blir det diskutert også hos dem.

For muslimene har jeg forstått at det ikke er noe religiøst påbud, men et spørsmål om renslighet og tradisjon. Tradisjoner har man lov å sette spørsmålstegn ved. Men hvorfor denne oppsto, er skjult. Argumentet «sand under preputiet» har jeg fra arabiske leger, men om det var unødvendig å nevne det, er det ubegrunnet å håne det.

Så til amerikansk praksis. Opplysninger om at majoriteten av nyfødte gutter blir omskåret ble kjent for meg først på 1940- til -50-tallet, og jeg ønsket å vite mer om det. Hva var den historiske bakgrunnen, og når og hvorfor startet det? (jf. første referanse i artikkelen). Svaret er 1860-årene, og en rekke artikler oppgir i de følgende 40-50 år at omskjæring er et utmerket tiltak mot onani. Dette er nå glemt og bare interessant som medisinsk historie. Først senere kom mulighetene for sammenlikning av større grupper omskårne og ikke-omskårne. Det er da funnet fordeler som nevnt av American Academy of pediatrics (AAP).

Da jeg spurte mine mange amerikanske slektninger hvorfor de var omskåret, svarte de at guttene ellers ville bli bedømt som sosial underklasse i gymnastikk og skole. Er dette en konfunderende faktor? Har man klart å korrigere disse sammenlikninger for generell hygiene, økonomi, medlem av diverse sykekasser og mer? Diverse kostnad-nytte-ratioer viser oftest forskjeller i omskjærings favør, men slett ikke alltid så bastant som Chaudhry og medforfattere gir uttrykk for.

Jeg kan forsikre om at jeg ikke føler det minste «ubehag» ved prosedyren. Men historiene om kjedelige komplikasjoner gjør meg opprørt, for jeg har sett for mange slike. Til slutt en oppfordring til dere som ivrer for omskjæring: Kan dere ikke vise solidaritet med de foreldre som ønsker omskjæring, organisere kirurgisk kompetanse og spare en barnerik innvandrerfamilie for den, i mine øyne, ublu betaling som kreves utenfor våre sykehus?

Helene Pande

helene.pande@getmail.no

Helene Pande (f. 1928) er pensjonert barnelege.

Ingen oppgitte interessekonflikter.

\footnotetext{
Litteratur

1. Pande H. Omskjæring kun på medisinsk indikasjon. Tidsskr Nor Legeforen 2012; 132: 2362

2. American Academy of Pediatrics Task Force on Circumcision. Circumcision policy statement. Pediatrics 2012; 130: 585-6.
} 